\title{
PENGARUH RETURN ON EQUITY, CURRENT RATIO DAN DEBT TO EQUITY RATIO TERHADAP HARGA SAHAM
}

\author{
Heny Ratnaningtyas \\ Sekolah Tinggi Pariwisata Trisakti-Jakarta \\ Email : heny.ratnaningtyas@stptrisakti.ac.id
}

\begin{abstract}
ABSTRAK
Penelitian ini bertujuan untuk mengetahui pengaruh return on equity, current ratio dan debt to equity ratio terhadap harga saham tahun 2017-2019. Populasi menggunakan 28 perusahaan, sedangkan sampel menggunakan 18 perusahaan pada perusahaan hotel, restoran dan pariwisata yang terdaftar di Bursa Efek Indonesia. Metode yang digunakan adalah regresi data panel. Berdasarkan hasil penelitian, secara parsial return on equity, current ratio dan debt to equity ratio berpengaruh signifikan terhadap harga saham. Pada penelitian ini menunjukkan bahwa return on equity yang tinggi mengindikasikan bahwa kinerja perusahaan sangat baik sehingga keuntungan investor menjadi meningkat, akhirnya tertarik menanamkan modalnya pada perusahaan akan berdampak pada naiknya harga saham. Sedangkan current ratio yang tinggi menunjukkan perusahaan mampu melunasi hutangnya dengan aktiva lancar, maka resiko likuidasi perusahaan semakin kecil dan resiko kerugian investor menjadi kecil pula, sehingga investor ingin menanamkan sahamnya pada perusahaan yang mempengaruhi kenaikan harga saham. Kemudian debt to equity ratio yang rendah menunjukkan bahwa keseluruhan kewajiban perusahaan lebih kecil dibandingkan dengan jumlah modal yang diperoleh dari investor, maka beban hutang perusahaan sangat rendah, maka laba perusahaan pun sangat tinggi, sehingga keuntungan investor menjadi meningkat dan mempengaruhi meningkatkanya harga saham.
\end{abstract}

Kata Kunci: Return On Equity, Current Ratio, Debt To Equity Ratio, Harga Saham

\section{PENDAHULUAN}

Pasar modal adalah tempat dimana berbagai pihak khususnya perusahaan menjual saham dan obligasi dengan tujuan dari hasil penjualan tersebut nantinya akan dipergunakan sebagai tambahan dan atau memperkuat modal perusahaan. Bursa Efek Indonesia (BEI) didirikan dengan tujuan menyelenggarakan perdagangan efek yang teratur, wajar dan efisien. Bursa Efek Indonesia bertugas untuk menyelenggarakan perdagangan efek yang teratur wajar dan efisien, menyediakan sarana pendukung serta mengawasi kegiatan anggota bursa efek, menyusun rancangan anggaran tahunan dan pengunaan laba Bursa Efek dan melaporkannya ke OJK (Budiman, 2017).

Perusahaan yang menjadi objek pada penelitian ini adalah perusahaan hotel, restoran, dan pariwisata mempunyai peranan yang sangat penting dalam meningkatkan perekonomian negara Indonesia. Banyak lokasi wisata di Indonesia dengan memiliki bermacam-macam keindahan alam, keragaman budaya tersendiri dan keunikan kelezatan kulinernya yang ada di bumi pertiwi menarik perhatian wisatawan nusantara dan wisatawan mancanegara untuk datang ke Indonesia. Hal ini akan menjadi kekuatan agar pariwisata di negara Indonesia dapat dikembangkan dan dikelola dengan baik sampai saat ini.

Perusahaan hotel, restoran, dan pariwisata, saat ini sangat dilihat dan merupakan daya tarik investor untuk menanamkan modalnya pada perusahaan tersebut karena segala usaha yang berhubungan dengan perusahaan tersebut akan berhubungan dengan kepariwisataan yang merupakan usaha yang bersifat komersial dengan tujuan utama mendatangkan devisa negara, menciptakan lapangan kerja bagi masyarakat, meningkatkan industri rakyat, memperluas kesempatan berusaha di sektor formal dan informal, membantu usaha pendidikan dan latihan, meningkatkan pendapatan pemerintah pusat dan pemerintah daerah, meningkatkan pendapatan masyarakat, pemerataan pembangunan, dan meningkatkan hubungan antar bangsa. 
Laporan keuangan pada perusahaan hotel, restoran dan pariwisata sangat berperan dalam menilai kinerja keuangan suatu perusahaan. Laporan keuangan menjadi pedoman untuk menentukan harga saham. Dengan tingginya harga saham, maka investor akan mendapatkan Return yaitu berupa Capital Gain sehingga citra perusahaan sangat berpengaruh untuk para investor. Dalam penelitian ini yang mempengaruhi harga saham adalah rasio keuangan meliputi Return On Equity (ROE), current ratio (CR) dan Debt to Equity Ratio (DER). Di dalam penelitian ini menggunakan ROE karena sebelum melakukan investasi, para investor wajib harus mengetahui ROE sebuah perusahaan. ROE tersebut menunjukkan efisiensi perusahaan dalam memanfaatkan ekuitas dan performa keuangannya secara keseluruhan. Intinya, ROE sangat penting untuk dilihat oleh investor, agar tidak buta melakukan sebuah investasi. Dengan ROE, setidaknya investor mengetahui masalah yang akan dihadapi nantinya. Semakin tinggi ROE, tandanya semakin efisien pula manajemen perusahaan dalam mencari pendapatan dan meningkatkan perkembangan dari pembiayaan ekuitas yang ada.

CR digunakan dalam penelitian ini karena para investor sebelum berinvestasi harus mengetahui kesehatan perusahaan yang ada pada rasio likuiditas yaitu CR yang menunjukkan likuiditas suatu perusahaan, seberapa mampu perusahaan dalam memenuhi kewajiban jangka pendeknya menggunakan aset jangka pendeknya. CR yang tinggi menunjukkan operasi perusahaan sehari-hari tidak akan terpengaruh oleh masalah modal kerja. Dengan kesehatan perusahaan menunjukkan bahwa perusahaan dalam keadaan yang baik dalam melaksanakan kegiatan operasionalnya.

Kemudian DER di dalam penelitian ini digunakan karena sebagian investor berpedoman bahwa DER perlu dilihat untuk mencermati utang perusahaan sekaligus bunga yang perlu dibayar oleh perusahaan dari utang tersebut. Bagi sebagian perusahaan, utang adalah aktivitas keuangan yang diperlukan untuk mendukung kegatan usahanya atau pengembangan usahanya. Dengan demikian, besaran utang tersebut menjadi perhatian bagi sebagian investor mengingat utang memiliki bunga yang perlu dibayar secara berkala oleh perusahaan. Apabila utang beserta bunganya terlalu besar maka hal tersebut dapat menggerus laba yang diperoleh perusahaan.

ROE menjadi ukuran bagi investor untuk melihat kemampuan perusahaan mendapatkan laba sebelum melakukan investasi karena menunjukkan keuntungan yang disediakan perusahaan untuk pemegang saham (Hanafi, 2008). ROE yang meningkat diikuti oleh meningkatnya harga saham, sehingga tingginya ROE akan memberikan kinerja perusahaan menjadi membaik, dimana modal yang dikelolanya dapat menghasilkan keuntungan bagi para investor (Puspita, 2011). Sedangkan CR merupakan alat ukur bagi para investor untuk mengetahui perusahaan memiliki aktiva lancar dapat memenuhi utang lancarnya, CR yang tinggi menunjukkan utang-utang perusahaan kepada kreditur dapat terjamin, laba yang diperoleh pun menjadi meningkat diikuti dengan peningkatan harga saham (Ismail, 2014). Kemudian yang menjadi ukuran bagi investor berikutnya adalah DER yang merupakan alat ukur perusahaan mampu dalam menjamin utang yang dimilikinya (Kasmir, 2011). Semakin tingginya DER menunjukkan resiko perusahaan menjadi lebih besar karena semua modal pinjaman yang dibutuhkan perusahaan untuk membayar seluruh hutangnya baik kewajiban jangka pendeknya maupun jangka panjangnya, maka laba yang diperoleh perusahaan akan digunakan untuk pengembalian pinjaman. Sehingga dampaknya para investor tidak tertarik berinvestasi yang akan mengakibatkan harga saham menjadi menurun (Suad dan Pudjiastuti, 2006).

\section{KAJIAN PUSTAKA Kinerja Keuangan}

Kinerja keuangan menurut (Sawir, 2015) adalah untuk menilai kondisi keuangan dan prestasi perusahaan, analisis memerlukan beberapa tolak ukur yang digunakan adalah ratio dan indeks, yang menghubungkan dua data keuangan antara satu dengan yang lain. Sedangkan menurut (Kurniasari, 2017), kinerja keuangan adalah prestasi kerja di bidang keuangan yang telah dicapai oleh perusahaan dan tertuang pada laporan keuangan dari perusahaan. Kinerja keuangan suatu perusahaan dapat dinilai dengan menggunakan alat analisis. Selanjutnya menurut (Fahmi, 2013), kinerja keuangan adalah cerminan berhasilnya perusahaan dalam bentuk hasil yang telah diperoleh karena kegiatan operasional yang dilakukannya. 
Tujuan kinerja keuangan perusahaan adalah sebagai berikut (Munawir, 2012):

1. Dapat mengetahui likuiditas perusahaan yaitu perusahaan mampu melunasi hutang/kewajiban jangka pendeknya dengan aktiva lancar.

2. Dapat mengetahui solvabilitas perusahaan yaitu perusahaan mampu melunasi hutang jangka pendeknya dan jangka panjangnya pada saat dilikuidasinya perusahaan.

3. Dapat mengetahui profitabilitas perusahaan yaitu perusahaan mampu mendapatkan laba.

4. Dapat mengetahui aktivitas perusahaan yaitu perusahaan mampu menggunakan tingkat penjualan dengan investasi yang ada di perusahaan.

\section{Rasio Keuangan}

Menurut (Ross, et al, 2009), rasio keuangan adalah menilai kinerja perusahaan pada laporan keuangan dengan membandingkan angka-angka untuk melihat keadaan keuangan perusahaan pada suatu periode. Sedangkan menurut Samryn (2011), analisis rasio keuangan adalah melakukan perbandingan angka keuangan yang ada pada perusahaan yang akan menjadikan lebih berarti yang merupakan pedoman kesehatan keuangan suatu perusahaan. Selanjutnya menurut Munawir (2012), analisis rasio keuangan adalah meramalkan kondisi keuangan dan laba perusahaan periode yang akan datang.

\section{Rasio Likuiditas}

Menurut (Rahardjo, 2007), rasio likuiditas yaitu rasio yang menjelaskan perusahaan mampu melunasi hutang/kewajiban jangka pendek, berikut adalah jenis rasio likuiditas:

1. Current ratio

Rasio ini menjelaskan bahwa perusahaan mampu segera melunasi hutangnya dengan aktiva lancar.

$$
\mathrm{CR}=\frac{\text { Aktiva Lancar }}{\text { Hutang Lancar }} \times 100 \%
$$

2. Quick Ratio

Rasio ini menjelaskan bahwa perusahaan mampu dengan segera melunasi hutangnya dengan likuid aktiva lancar.

$\mathrm{QR}=\underline{\text { Aktiva Lancar-Persediaan }} \times$ 100\%

3. Cash Ratio

$$
\text { Hutang Lancar }
$$

Rasio ini menjelaskan bahwa perusahaan mampu segera melunasi hutangnya dengan sejumlah kas perusahaan yang dimilikinya.

$$
C R=\frac{\text { Kas }+ \text { Setara Kas }}{\text { Hutang Lancar }} \times 100 \%
$$

\section{Rasio Profitabilitas}

Menurut (Kasmir, 2011), rasio profitabilitas adalah rasio yang menjelaskan bahwa perusahaan mampu untuk mendapatkan keuntungan, berikut adalah jenis rasio profitabilitas tersebut:

1. Net profit margin (NPM)

Rasio ini menunjukkan laba bersih setelah bunga dan pajak perusahaan atas produk/jasa yang dijual perusahaan. Semakin besar NPM maka keuntungan yang diperoleh perusahaan meningkat karena perusahaan dapat menentukan harga produk, menekan dan biaya yang ada dapat dikendalikan dengan baik.

$\mathrm{NPM}=\underline{\text { Laba bersih setelah bunga dan pajak }} \times 100 \%$

\section{Penjualan bersih}

2. Return on asset (ROA)

ROA adalah rasio yang menjelaskan perusahaan mampu mengelola semua aktiva secara efektif dan efisien untuk mendapatkan keuntungan setelah bunga dan pajak.

$\mathrm{ROA}=\underline{\text { Laba bersih setelah bunga dan pajak }} \times 100 \%$

\section{Total Aktiva}


3. Return on equity (ROE)

ROE adalah rasio yang menjelaskan perusahaan mampu mendapatkan laba dengan modal yang didapatkan dari investor yang menanamkan modalnya pada perusahaan.

ROE $=\underline{\text { Laba bersih setelah bunga dan pajak } x 100 \%}$

Total Ekuitas

\section{Rasio Solvabilitas}

Menurut (Sutrisno, 2009), rasio solvabilitas adalah rasio yang menjelaskan perusahaan mampu melunasi seluruh hutang jangka pendek dan panjangnya jika dilikuidasinya perusahaan, berikut adalah jenis rasio solvabilitas:

1. Debt to Assets Ratio (DAR)

Rasio ini menjelaskan berapa besarnya aktiva yang dikelola dan dimiliki perusahaan yang dibiayai dengan hutang.

DAR $=\underline{\text { Total Hutang }} \times 100 \%$

Total Aktiva

2. $\quad$ Debt to Equity Ratio (DER)

Rasio ini menjelaskan berapa besarnya modal yang dijadikan jaminan hutang perusahaan.

DER $=\underline{\text { Total Hutang }} \times 100 \%$

Total Ekuitas

3. Long Term Debt to Equity Ratio (LTDER)

Rasio ini mengukur total hutang jangka panjang dengan ekuitas.

LTDER = Total Hutang Jangka Panjang $x$ 100\%

Total Ekuitas

4. Times Interest Earned Ratio (TIER)

Rasio ini mengukur perusahaan mampu mampu melunasi biaya bunga dari kewajibannya. Rumus

Times Interest Earned Ratio:

TIER $=\underline{\text { Earning Before Income Tax }} \times 100 \%$

Biaya Bunga

Rasio Aktivitas

Menurut Syamsuddin (2009), rasio aktivitas adalah rasio yang menjelaskan kemampuan keefektifan perusahaan menggunakan tingkat penjualan dengan investasi yang ada di perusahaan, berikut adalah Rasio aktivitas:

1. Total Asset Turn Over (perputaran aktiva)

Total assets turn over adalah rasio yang menjelaskan perusahaan mampu mengelola seluruh aktiva secara efisiensi untuk meningkatkan jumlah penjualan.

TATO $=\frac{\text { Penjualan Bersih }}{\text { Total asset rata-rata }} \times 100 \%$

2. Inventory Turn Over (Rasio Perputaran Persediaan)

Inventory turn over adalah rasio yang menjelaskan perusahaan mampu menggunakan dana yang ada pada investasi dan dana tersebut dalam periode tertentu dapat berputar dengan baik.

$\mathrm{ITO}=\frac{\text { Harga Pokok Penjualan }}{\text { Rata-rata persediaan }} \times 100 \%$

3. Working Capital Turn Over (Rasio Perputaran Modal Kerja)

Working capital turn over adalah rasio yang menjelaskan perusahaan mampu menggunakan moda kerja dalam suatu periode siklus kas dapat berputar dengan baik.
$\mathrm{WCTO}=$
Penjualan
x $100 \%$
Modal kerja rata-rata 
4. Rasio Perputaran Piutang (Accounts Receivable Turn Over)

Accounts receivable turn over adalah rasio yang menjelaskan perusahaan mampu mengelola piutang yang untuk mendapatkan tingkat penjualan yang tinggi.

$\mathrm{ARTO}=\underset{\text { Rata-rata piutang bersih }}{\text { Penjualan Bersih }} \times 100 \%$

5. Rasio Perputaran Hutang (Accounts payable turn over)

Rasio ini untuk menjelaskan perusahaan mampu membayar hutang kepada kreditur setahun beberapa kali.

$$
\text { APTO }=\frac{\text { Harga Pokok Penjualan }}{\text { Hutang Usaha }} \times 100 \%
$$

6. Rasio Perputaran Kas (Cash Turn Over)

Rasio ini menjelaskan efisiensinya kas yang digunakan oleh perusahaan sebagai alat ukur bahwa kas yang dimiliki perusahaan sudah berapa kali dibelanjakan selama beberapa periode. Berikut rumus cash turn over:

$$
\mathrm{CTO}=\underset{\text { Kas Rata-rata dan Setara Kas }}{\text { Penjualan }} \times 100 \%
$$

\section{Harga Saham}

Menurut (Widoatmodjo, 2012), harga saham adalah harga atau nilai uang yang bersedia dikeluarkan untuk memperoleh atas suatu saham. Selanjutnya menurut (Darmadji \& Fakhrudin, 2012), harga saham terjadi di bursa pada waktu tertentu, harga saham bisa berubah naik atau pun turun dalam hitungan waktu yang begitu cepat dan dapat berubah dalam hitungan menit bahkan dapat berubah dalam hitungan detik. Hal tersebut dimungkinkan karena tergantung dengan permintaan dan penawaran antara pembeli saham dengan penjual saham. Jenis harga saham adalah sebagai berikut (Widoatmojo, 2012):

1. Harga Nominal

Harga yang tertera pada lembaran saham yang telah ditentukan oleh emiten pada setiap lembar saham.

2. Harga Perdana

Harga untuk pertama kalinya tercatat di bursa saham yag biasanya ditentukan oleh penjamin emisi (underwrite) dan emiten.

3. Harga Pasar

Harga yang sedang terjadi pada saat ini dan tercatat pada bursa saham, harga ini merupakan harga yang ditentukan oleh perusahaan penerbitnya, karena terjadinya kesepakatan antara harga investor dengan harga perusahaan penerbitnya.

4. Harga pembukaan

Harga yang diminta oleh penjual/pembeli pada saat sedang pembukaan bursa saham, saat itu pula transaksi saham akan dimulai dan terjadi dan harga saham berdasarkan permintaan penjual dan pembeli.

5. Harga Penutupan

Harga yang tercatat pada saat penutupan akhir bursa. Pada saat akhir hari bursa bisa saja terjadi transaksi atas suatu saham, karena ada kesepakatan antara penjual dengan pembeli.

6. Harga Tertinggi

Harga yang tertinggi pada saat hari bursa dan transaksi atas saham dilakukan lebih dari satu kali tidak pada harga yang sama.

7. Harga Terendah

Harga terjadi apabila terjadi transaksi atas suatu saham lebih dari satu kali tidak pada harga yang sama. Dengan kata lain, harga terendah merupakan lawan dari harga tertiggi.

8. Harga Rata-Rata

Harga rata-rata merupakan perataan dari harga tertinggi dan terendah. 
Berikut adalah faktor yang dapat mempengaruhi naik turunnya harga saham di Bursa Efek Indonesia (Brigham dan Houston, 2017) yaitu:

1. Faktor internal

a. Pengiklanan, rincian kontrak, perubahan harga, penarikan produk baru, laporan produksi, laporan keamanan, dan laporan penjualan.

b. Ekuitas dan hutang.

c. Perubahan dan pergantian direktur, manajemen dan struktur organisasi.

d. Laporan merger investasi, investasi ekuitas, laporan take over oleh pengakuisisian dan diakuisisi, laporan investasi.

e. Ekspansi pabrik pengembangan riset dan penutupan usaha.

f. Pengumuman ketenagakerjaan

g. Pengumuman laporan keuangan

2. Faktor eksternal

a. suku bunga tabungan, suku bunga deposito kurs valuta asing, inflasi, regulasi dan regulasi ekonomi.

b. Tuntutan terhadap perusahaan atau terhadap manajernya dan tuntutan perusahaan terhadap manajernya.

c. Laporan insider trading dan harga saham perdagangan pembatasan

\section{Hipotesis}

Pengaruh Return on equity Terhadap Harga Saham

Return on equity (ROE) dihitung berdasarkan laba bersih setelah bunga dan pajak dibagi dengan total ekuitas. Semakin tinggi ROE yang diperoleh perusahaan, maka semakin baik pula hak yang diberikan pemegang saham. Hal ini akan berdampak pada daya tarik investor menanamkan modalnya pada perusahaan yang akan diikuti oleh kenaikan harga saham. Penelitian oleh (Wulandari \& Badjra, 2019) serta )Nurfadillah, 2011), menunjukkan bahwa ROE yang tinggi memperlihatkan bahwa pengelolaan modal yang dilakukan perusahaan dalam menghasilkan laba menjadi meningkat dan keuntungan untuk para pemegang saham akan menjadi lebih baik, ini akan mempengaruhi kenaikan harga saham, maka hipotesis dalam penelitian ini adalah:

$\mathrm{H}_{1}$ : Return on equity berpengaruh signifikan terhadap harga saham

\section{Pengaruh Rasio Likuiditas Terhadap Harga Saham}

Current ratio (CR) dihitung berdasarkan aktiva lancar dibagi dengan hutang lancar. Hasil Penelitian yang dilakukan oleh oleh (Sriwahyuni \& Saputra, 2017) serta (Pratama \& Erawati, 2014) menunjukkan bahwa CR yang tinggi berarti semakin baik hutang jangka pendek dilunasi perusahaan, maka semakin kecil resiko likuidasi yang dialami perusahaan sehingga resiko yang ditanggung pemegang saham juga semakin kecil. Hal ini menjadikan keputusan yang positif bagi investor untuk membeli saham perusahaan, sehingga permintaan akan saham perusahaan pun meningkat, maka harga saham menjadi meningkat. Berdasarkan uraian diatas, maka hipotesis dalam penelitian ini dapat dikembangkan sebagai berikut:

$\mathrm{H}_{2}$ : Current ratio berpengaruh signifikan terhadap harga saham

\section{Pengaruh Rasio Solvabilitas Terhadap Harga Saham}

Debt to equity ratio (DER) dihitung berdasarkan total hutang dibagi dengan dengan total ekuitas. Tingginya DER menunjukkan perusahaan sangat tergantung pada modal yang diperoleh perusahaan dari pemegang saham, sehingga semakin berat beban utang yang dialami perusahaan, maka hal tersebut mempengaruhi keputusan investor untuk tidak membeli saham perusahaan, akibatnya harga saham perusahaan menjadi menurun. Penelitian yang dilakukan (Hendra, 2019) serta (Ramadhani \& Pustikaningsih, 2017) menunjukan bahwa DER berpengaruh signifikan dan negatif terhadap harga saham, maka hipotesis dalam penelitian ini dapat dikembangkan sebagai berikut:

$\mathrm{H}_{3}$ : Debt to equity ratio berpengaruh signifikan terhadap harga saham 


\section{METODE PENELITIAN}

\section{Populasi dan Sampel}

Populasi yang peneliti gunakan kali ini adalah perusahaan sub sektor hotel, restoran, dan pariwisata yang sudah ada di dalam Bursa Efek Indonesia sebanyak 28 perusahaan. Sampel penelitian ini menggunakan metode purposive sampling yaitu sampel diambil berdasarkan pertimbangan dan kriteria peneliti, yaitu sebagai berikut:

1. Perusahaan merupakan perusahaan sub sektor hotel, restoran, dan pariwisata yang terdaftar di BEI

2. Perusahaan Sub sektor hotel, restoran, dan pariwisata yang melaporkan Laporan Keuangan Tahunan secara kontinyu selama tahun 2017-2019.

3. Perusahaan sampel bukan perusahaan yang sedang mengalami kerugian ditahun tersebut.

4. Memiliki data lengkap

Berdasarkan kriteria di atas, maka sampel dalam penelitian ini terdiri dari 18 perusahaan hotel, restoran dan pariwisata yang terdaftar di Bursa Efek Indonesia, yaitu:

Tabel 1. Sampel Penelitian

\begin{tabular}{|c|l|}
\hline No & \multicolumn{1}{|c|}{ Perusahaan } \\
\hline 1 & PT. Bayu Buana \\
\hline 2 & PT. Bukit Uluwatu Villa \\
\hline 3 & PT. Fast Food Indonesia \\
\hline 4 & PT. Saraswati Griya Lestari \\
\hline 5 & PT. Island Concepts Indonesia \\
\hline 6 & PT. Indonesian Paradise Property \\
\hline 7 & PT. Jakarta Setiabudi International \\
\hline 8 & PT. Panorama Sentrawisata \\
\hline 9 & PT. Destinasi Tirta Nusantara \\
\hline 10 & PT. Pembangunan Graha Lestarri Indah \\
\hline 11 & PT. Pembangunan Jaya Ancol \\
\hline 12 & PT. Plaza Indonesia Reality \\
\hline 13 & PT. Pudjiadi and sons \\
\hline 14 & PT. J Resources Asia Pasifik \\
\hline 15 & PT. Red Planet Indonesia Tbk \\
\hline 16 & PT. Pioneerindo Gourmet International \\
\hline 17 & PT. Pudjiadi Prestige \\
\hline 18 & PT. Hotel Sahid Jaya International \\
\hline
\end{tabular}

Data laporan tahunan tersebut merupakan data sekunder yang digunakan oleh peneliti untuk menghitung ROE, CR, dan DER selama 3 tahun sehingga sampel yang diperoleh adalah 18 perusahaan dikalikan dengan 3 tahun yang berarti ada 54 sampel perusahaan.

\section{Variabel Bebas}

Variabel bebas adalah variabel yang menjadi penyebab berubahnya variabel terikat (Sugiyono, 2016). Dalam penelitian ini variabel bebas yang digunakan adalah:

1. Return on equity (ROE)

ROE adalah rasio yang menjelaskan perusahaan mampu mendapatkan laba dengan modal yang didapatkan dari investor yang menanamkan modalnya pada perusahaan (Kasmir, 2011).

ROE $=$ Laba bersih setelah bunga dan pajak $\times 100 \%$

\section{Total Ekuitas}

2. Current ratio (CR) sebagai variabel $\mathrm{X}_{2}$

Rasio ini menjelaskan bahwa perusahaan mampu segera melunasi hutangnya dengan aktiva lancar (Rahardjo, 2007).

$$
\mathrm{CR}=\frac{\text { Aktiva Lancar }}{\text { Hutang Lancar }} \times 100 \%
$$


3. Debt to equity ratio (DER) sebagai variabel $\mathrm{X}_{3}$

DER adalah rasio yang menjelaskan berapa besarnya modal yang dijadikan jaminan hutang perusahaan (Sutrisno 2009).

$$
\text { DER }=\frac{\text { Total Hutang }}{\text { Total Ekuitas }} \times 100 \%
$$

\section{Variabel Terikat}

Variabel terikat adalah variabel yang dipengaruhi atau menjadi akibat, karena adanya variabel bebas (Sugiyono, 2016). Variabel terikat yang digunakan dalam penelitian ini adalah harga saham (Y). Harga saham adalah harga penutupan yang ditentukan berdasarkan permintaan dan penawaran di pasar penjualan dan pembelian saham (Widioatmojo, 2015).

Metode yang digunakan dalam penelitian ini adalah analisis regresi data panel. Model penelitian yang akan digunakan dalam penelitian ini adalah:

$$
Y=\alpha_{1}+\beta_{1} X_{1 i t}+\beta_{2} X_{2 i t}++\beta_{3} X_{3 i t}+\varepsilon_{\text {it }}
$$

Keterangan:

Y : Harga Saham

$\mathrm{X}_{1 \text { it }} \quad$ : Return on asset

$\mathrm{X}_{2 \text { it }} \quad$ : Current ratio

$\mathrm{X}_{3 \mathrm{it}} \quad$ : Debt to equity ratio

$\beta_{1,2,3}$ : Koefisien jalur

$\alpha_{\text {it }} \quad:$ Konstanta

$\varepsilon_{\mathrm{it}} \quad:$ Error

\section{HASIL DAN PEMBAHASAN \\ HASIL \\ Uji Chow}

Tabel 2. Uji Chow

\begin{tabular}{llll}
\hline \hline Effects Test & Statistic & d.f. & Prob. \\
\hline \hline Cross-section F & 19.423655 & $(17,33)$ & 0.0000 \\
Cross-section Chi-square & 129.516406 & 17 & 0.0000 \\
\hline \hline
\end{tabular}

Sumber: Data diolah (2020)

Uji Chow digunakan untuk memilih model yang terbaik apakah common effect atau fixed effect (Gujarati 2012). Pada uji Chow, apabila nilai cross-section F > 0,05 maka model yang dipilih adalah common effect dan apabila nilai cross-section. $\mathrm{F}<0,05$ maka model yang dipilih adalah fixed effect (Gujarati 2012). Pada tabel 3 menunjukkan bahwa nilai cross-section $\mathrm{F}(0,0000)<0,05$, sehingga model yang dipilih adalah fixed effect.

\section{Uji Hausman}

Tabel 3. Uji Hausman

\begin{tabular}{lccc}
\hline \hline Test Summary & Chi-Sq. Statistic & Chi-Sq. d.f. & Prob. \\
\hline \hline Cross-section random & 0.506480 & 3 & 0.0482 \\
\hline \hline
\end{tabular}

Sumber: Data diolah (2020) 
Uji Hausman digunakan untuk memilih model yang terbaik apakah fixed effect atau random effect (Gujarati 2012). Pada uji Hausman, apabila nilai cross-section random > 0,05 maka model yang dipilih adalah random effect dan apabila $<0,05$ maka model yang terpilih adalah fixed effect (Gujarati 2012). Pada tabel 4 menunjukkan bahwa nilai cross-section random $(0,0482)<0,05$ sehingga model yang dipilih adalah fixed effect.

\section{Uji Hipotesis}

Uji t

Uji statistik $\mathrm{t}$ menunjukkan seberapa jauh pengaruh variabel bebas secara individual dalam menerangkan variasi variabel terikat. Uji ini dilakukan dengan memperbandingkan t-hitung dengan t-tabel (Widarjono, 2013).

Tabel 4. Uji t

\begin{tabular}{crrrr} 
Variable & Coefficient & Std. Error & t-Statistic & Prob. \\
\hline \hline C & 11.70764 & 9.628300 & 12.15961 & 0.0000 \\
ROE? & 2.273479 & 0.223788 & 9.882461 & 0.0172 \\
CR? & 1.879131 & 0.267727 & 7.215107 & 0.0451 \\
DER? & -2.269568 & 0.218759 & -10.36274 & 0.0248 \\
Fixed Effects (Cross) & & & \\
_BAYU--C & 0.788732 & & \\
_BUVA--C & -1.188028 & & \\
_FAST--C & 3.175017 & & \\
_HOTL--C & -1.874030 & & \\
_ICON--C & 4.058915 & & \\
_INPP--C & 5.044363 & & \\
_JSPT--C & 1.843058 & & \\
_PANR--C & -5.684403 & & \\
_PDES--C & -2.428775 & & \\
_PGLI--C & 1.962024 & & \\
_PJAA--C & 0.546551 & & \\
_PLIN--C & 1.572497 & & \\
_PNSE--C & -0.897997 & & \\
_PSAB--C & 1.299616 & & \\
_PSKT--C & -2.599375 & & \\
_PTSP--C & 0.789457 & & \\
_PUDP--C & 2.654901 & & \\
_SHID--C & -0.845723 & & \\
\hline \hline
\end{tabular}

Effects Specification

Cross-section fixed (dummy variables)

\begin{tabular}{lrlr}
\hline \hline R-squared & 0.653300 & Mean dependent var & 22.96093 \\
Adjusted R-squared & 0.624996 & S.D. dependent var & 189.2737 \\
S.E. of regression & 5.333600 & Akaike info criterion & 7.168441 \\
Sum squared resid & 2357.481 & Schwarz criterion & 7.183175 \\
Log likelihood & -473.4792 & Hannan-Quinn criter. & 7.174123 \\
F-statistic & 23.68163 & Durbin-Watson stat & 1.556128 \\
Prob(F-statistic) & 0.000000 & & \\
\hline
\end{tabular}

Sumber: Data diolah (2020) 
Uji t dilakukan untuk mengetahui apakah variabel bebas secara parsial memiliki pengaruh yang signifikan terhadap variabel terikat (Widarjono, 2013). Uji t dilakukan dengan $\alpha=5 \%$, maka diperoleh ttabel yaitu 1,67356, maka kesimpulan nya adalah sebagai berikut:

1. Uji ROE $\left(\mathrm{X}_{1}\right)$ terhadap harga saham $(\mathrm{Y})$, dengan melihat tabel 5, nilai t-hitung $(9,882461)>$ nilai ttabel $(1,67356)$ dan nilai probabilitas $(0,0172)<0,05$ maka $\mathrm{H}_{01}$ ditolak dan $\mathrm{H}_{\mathrm{a} 1}$ diterima, dapat disimpulkan bahwa return on equity berpengaruh signifikan terhadap harga saham.

2. Uji CR $\left(\mathrm{X}_{2}\right)$ terhadap harga saham $(\mathrm{Y})$, dengan melihat tabel 5, nilai t-hitung (7.215107) > nilai ttabel $(1,67356)$ dan nila probabilitas $(0,0451)<0,05$ maka $\mathrm{H}_{02}$ ditolak dan $\mathrm{H}_{\mathrm{a} 2}$ diterima, dapat disimpulkan bahwa current ratio berpengaruh signifikan terhadap harga saham.

3. Uji DER $\left(\mathrm{X}_{3}\right)$ terhadap harga saham $(\mathrm{Y})$, dengan melihat tabel 5, nilai t-hitung (-10.36274) > nilai ttabe $(-1,67356)$ dan nilai probabilitas $(0.0248)<0,05$ maka $\mathrm{H}_{03}$ ditolak dan $\mathrm{H}_{\mathrm{a} 3}$ diterima, dapat disimpulkan bahwa debt to equity ratio berpengaruh signifikan terhadap harga saham.

\section{Uji F}

Uji F dilakuka untuk mengetahui apakah semua variabel bebas secara bersama-sama berpengaruh signifikan terhadap variabel terikat (Widarjono, 2013). Hasil yang diperoleh dari tabel 5, didapat nilai Fhitung $(23.68163)>$ nilai F-tabel $(2,78)$ dan nilai probabilitas F-hitung $(0,000000)<0,05$ maka $\mathrm{H}_{0}$ ditolak dan $\mathrm{H}_{1}$ diterima. Dengan demikian, dapat disimpulkan bahwa variabel bebas (ROE, CR dan DER) berpengaruh signifikan secara bersama-sama terhadap Harga Saham.

\section{Uji Adjusted $\mathbf{R}^{2}$}

Nilai adjusted $\mathrm{R}^{2}$ dilakukan untuk mengetahui berapa persen kemampuan variabel bebasnya dalam menjelaskan variabel terikatnya di dalam garis regresi (Widarjono, 2013). Dari tabel 5 di atas menunjukan bahwa kemampuan variabel ROE, CR dan DER dalam menjelaskan variabel harga saham adalah sebesar $62,49 \%$, sisanya sebesar $37,51 \%$ dijelaskan oleh variabel lain di luar penelitian ini.

\section{PEMBAHASAN}

Return on equity berpengaruh signifikan terhadap harga saham karena return on equity pada perusahaan hotel, restoran dan pariwisata yang tinggi mengindikasikan bahwa kinerja yang diperoleh perusahaan sangat baik sehingga keuntungan yang diterima oleh pemegang saham meningkat. Dengan meningkatnya keuntungan tersebut menjadikan investor tertarik menanamkan modalnya di perusahaan hotel, restoran dan pariwisata sehingga akan berdampak pada naiknya harga saham. Sebelum berinvestasi, para investor menggunakan return on equity sebagai alat ukur yang menunjukkan efisiensi perusahaan dalam memanfaatkan ekuitas dan performa keuangannya secara keseluruhan. Return on equity digunakan investor agar tidak buta melakukan sebuah investasi dan mengetahui masalah yang akan dihadapi nantinya. Semakin tinggi return on equity, maka semakin efisien pula manajemen perusahaan dalam mencari pendapatan dan meningkatkan perkembangan dari pembiayaan ekuitas yang ada.

Current ratio berpengaruh signifikan terhadap harga saham karena current ratio yang tinggi pada perusahaan hotel, restoran dan pariwisata menunjukkan bahwa perusahaan mampu untuk melunasi kewajiban jangka pendeknya dengan aktiva lancar yang dimiliki perusahaan, maka resiko likuidasi yang dibebankan oleh perusahaan semakin kecil dan pemegang saham pun memiliki resiko kerugian yang kecil pula. Hal ini menjadikan tingginya investor menanamkan sahamnya pada perusahaan yang akan mempengaruhi pada kenaikan harga saham. Sebelum berinvestasi para investor harus mengetahui kesehatan perusahaan yang ada pada current ratio yang menunjukkan seberapa mampu perusahaan dalam memenuhi kewajiban jangka pendeknya menggunakan aset jangka pendeknya. Current ratio yang tinggi menunjukkan operasi perusahaan sehari-hari tidak akan terpengaruh oleh masalah modal kerja. Dengan kesehatan perusahaan menunjukkan bahwa perusahaan dalam keadaan yang baik dalam melaksanakan kegiatan operasionalnya.

Debt to equity ratio berpengaruh signifikan terhadap harga saham karena debt to equity ratio yang rendah pada perusahaan hotel, restoran dan pariwisata menunjukkan bahwa keseluruhan hutang/kewajiban jangka pendek dan panjangnya yang dimiliki perusahaan lebih kecil dibandingkan dengan jumlah modal yang diperoleh dari investor, maka beban hutang yang ditanggung oleh perusahaan 
pun sangat rendah, maka akan mengakibatkan pada jumlah laba yang diterima oleh perusahaan sangat tinggi, sehingga keuntungan yang diterima oleh pemegang saham menjadi meningkat, hal ini akan mempengaruhi meningkatkanya harga saham. Investor berpedoman bahwa DER karena untuk mencermati utang perusahaan sekaligus bunga yang perlu dibayar oleh perusahaan dari utang tersebut. Bagi sebagian perusahaan, utang adalah aktivitas keuangan yang diperlukan untuk mendukung kegatan usahanya atau pengembangan usahanya. Dengan demikian, besaran utang tersebut menjadi perhatian bagi sebagian investor mengingat utang memiliki bunga yang perlu dibayar secara berkala oleh perusahaan. Apabila utang beserta bunganya terlalu besar maka hal tersebut dapat menggerus laba yang diperoleh perusahaan

\section{KESIMPULAN}

Berdasarkan penelitian tentang pengaruh kinerja keuangan terhadap harga saham pada perusahaan hotel, restoran dan pariwisata yang terdaftar di Bursa Efek Indonesia, maka kesimpulan yang diperoleh adalah sebagai berikut:

1. Adanya pengaruh signifikan return on equity terhadap harga saham mengindikasikan bahwa kinerja perusahaan semakin efisien dalam menggunakan modal sendiri untuk menghasilkan laba atau keuntungan bersih sehingga return on equity perusahaan semakin tinggi. Return on equity yang tinggi cenderung meningkatkan minat investor terhadap saham karena menganggap perusahaan tersebut mempunyai prospek yang baik dalam meningkatkan laba. Apabila minat investor meningkat terhadap suatu saham, maka harga saham tersebut akan meningkat.

2. CR berpengaruh signifikan terhadap harga saham karena CR yang tinggi menunjukkan bahwa perusahaan mampu untuk melunasi kewajiban jangka pendeknya dengan aktiva lancar yang dimiliki perusahaan, maka resiko likuidasi yang dibebankan oleh perusahaan semakin kecil dan pemegang saham pun memiliki resiko kerugian yang kecil pula. Hal ini menjadikan tingginya investor menanamkan sahamnya pada perusahaan yang akan mempengaruhi pada kenaikan harga saham.

3. Debt to equity ratio berpengaruh signifikan terhadap harga saham. Debt to equity ratio menunjukkan positif, hal ini mengindikasikan bahwaperusahaan terus tumbuh dan mengembangkan produk-produk baru (ekspansi). Perusahaan yang tumbuh hampir pasti akan memerlukan pendanaan yang cukup besar untuk mendanai operasional perusahaan yang tidak mungkin dapat dipenuhi hanya dari modal sendiri yang dimiliki perusahaan. Pengembangan perusahaan ini diharapkan perusahaan mampu memberikan keuntungan yang lebih besar di tahun mendatang.

\section{SARAN}

Saran yang dapat peneliti berikan terkait dengan penelitian ini adalah sebagai berikut:

1. Bagi perusahaan dan investor hendaknya memperhatikan kemampuan perusahaan dalam menghasilkan profit, kemampuan perusahaan membayar hutang jangka pendeknya dengan aktiva lancar dan kemampuan perusahaan untuk memenuhi seluruh hutangnya dengan modal/ekuitas yang dimiliki. Hal ini karena berdasarkan hasil penelitian, rasio profitabilitas (return on equity), likuiditas (current ratio) dan rasio solvabilitas (debt to equity ratio) merupakan faktor yang dominan dalam mempengaruhi harga saham.

2. Bagi Peneliti selanjutnya sebaiknya menambahkan variabel fundamental yang belum dimasukkan dalam penelitian ini dan objek dalam penelitian dapat menggunakan kelompok perusahaan lainnya yang terdaftar di Bursa Efek Indonesia.

\section{REFERENSI}

Brigham, E.F., \& Houston, J.F. (2017). Dasar-Dasar Manajemen Keuangan. Salemba Empat: Jakarta.

Budiman, Raymod. (2017). Investing Is Easy: Teknik Analisa Dan Strategi Investasi Saham Untuk Pemula. Jakarta: Erlangga.

Fahmi, I. (2013). Analisis Kinerja Keuangan. Bandung: Alfabeta.

Gujarati, Damodar. (2012). Dasar-dasar Ekonometrika. Salemba: Jakarta. 
Hanafi, Mamduh M. (2008). Manajemen Keuangan. Yogyakarta: BPFE.

Hendra, D. (2019). Pengaruh Debt To Equity Ratio (DER), Current Ratio (CR), Return On Asset (ROA) Dan Return On Equity (ROE) Terhadap Harga Saham Dan Implikasinya Terhadap Return Saham Pada Industri Penerbangan (Studi Kasus Pada Perusahaan Maskapai Asia). KREATIF: Jurnal Ilmiah Prodi Manajemen Universitas Pamulang, 7(1), 80-92.

Ismail. (2014). Perbankan Syariah. Jakarta: Kencana.

Kasmir. (2011). Analisa Laporan Keuangan. Bumi Aksara: Jakarta.

Kurniasari, Rani. (2017). Analisis Return On Assets (ROA) dan Return On Equity Terhadap Rasio Permodalan (Capital Adequacy Ratio) Pada PT Bank Sinarmas Tbk. Jurnal Moneter Vol. IV No. 2, 150-158.

Munawir. (2012). Analisa Laporan Keuangan. Yogyakarta: Liberty Yogyakarta.

Nurfadillah, Mursidah. (2011). Analisis Pengaruh Earning Per Share, Debt to Equity Terhadap Harga Saham PT. Unilever Indonesia, Tbk. Jurnal Manajemen dan Akuntansi, Volume 12, Nomor 1, Hal 45-50.

Pratama, Aditya., \& Erawati, Teguh. (2014) Pengaruh Current Ratio, Debt to Equity, Return on Equity, Net Profit Margin dan Earning Per Share Tehadap Harga Saham (Study Kasus Pada Perusahaan Manufaktur di Bursa Efek Indonesia Periode 2008-2011). Jurnal Akuntansi, Vol, 2 No.1, 1-10.

Puspita, Novita Santi. (2011). Analisis Pengaruh Struktur Modal, Pertumbuhan Perusahaan, ukuran Perusahaan, dan profitabilitas terhadap Nilai Perusahaan. Skripsi. Universitas Diponegoro Semarang.

Rahardjo. Budi. (2007). Keuangan dan Akuntansi. Yogyakarta: Graha Ilmu.

Ramadhani, Fendi Hudaya., \& Pustikaningsih, Adeng. (2017). Pengaruh Debt to Equity (DER), Return on Equity (ROE) dan Net Profit Margin (NPM) Terhadap Harga Saham Perusahaan Sektor Pertambangan Yang Tedaftar di Bursa Efek Indonesia Periode 2011-2015. Jurnal Profita Edisi 8, $1-13$.

Ross, Stephen., Randolph, Westerfield., \& Bradford, Jordan. (2009). Fundamentals of Corporate Finance. New York: Mcgraw-Hill.

Samryn. (2011). Pengantar Akuntansi Mudah Membuat Jurnal Dengan Pendekatan Siklus Transaksi. Jakarta: PT. Raja Grafindo Persada.

Sawir, Agnes. (2015). Analisis Kinerja Keuangan dan Perencanaan Keuangan Perusahaan. Jakarta: Gramedia.

Sriwahyuni, Endah., \& Saputra, Rishi Septa (2017). Jurnal Online Akuntan, Vol.2, No.1 Juni, 119-136.

Suad, Husnan., \& Pudjiastuti, Eny. (2006). Dasar-Dasar Manajemen Keuangan. Yogyakarta: UPP STIM YKPN.

Sugiyono. (2016). Metode Penelitian Kuantitatif, Kualitatif dan R\&D. Bandung: Alfabeta.

Sundjaja, Inge Barlian. (2003). Manajemen Keuangan. Jakarta: Literata Lintas Media.

Sutrisno. (2009), Manajemen Keuangan Teori, Konsep dan Aplikasi. Yogyakarta: Ekonisia.

Syamsuddin. (2009), Manajemen Keuangan Perusahaan. Jakarta: PT. Raja Grafindo.

Widarjono, Agus. (2013). Ekonometrika Pengantar dan aplikasinya. Jakarta: Ekonosia.

Widoatmojo, Sawidji. (2012). Cara Sehat Investasi di Pasar Modal. Jakarta: PT. Elex Media Komputindo.

Wulandari, Ade Indah., \& Badjra, Ida Bagus. (2019). Pengaruh Profitabilitas Terhadap Harga Saham Pada Perusahaan LQ-45 Di Bursa Efek Indonesia (BEI). E-Jurnal Manajemen, Vol.8, No.9, $5722-5740$. 